ŁUKASZ WAWRZYNEK

\title{
Using the organizational network analysis to build competitiveness on the example of enterprise energy sector
}

Łukasz Wawrzynek, Ph.D. Wrocław University of Economics Department of Management Systems Design

\section{Introduction}

Contemporary organizations operate in intensely competitive markets, whose primary feature is the rapid change of both the clients' expectations and, in some cases, of products and services supplied. Under such conditions an organization, in order to remain competitive, must implement internal interventions - its reaction to the changing environment. In order to effectively compete, the organizations must seek solutions which are innovative on one hand, and on the other hand are matched to their capacities - in order to ensure a synergy effect. The challenge for the organizations lies not only in understanding requirements of the market and reacting quickly to them, but also in achieving internal efficiency that would support the organizational changes being implemented. To cope with these requirements, organizations should understand the internal conditions and use them to shape their competitive advantage. Such situation offers a space for the search for opportunities to develop an instrumental approach to defining factors which on one hand determine the organization's identity, and on the other hand build the basis to 
maintain or achieve competitive position in the market (Wawrzynek 2012, p. 157).

Competitiveness of organizations, according to the Porter's theorem (Porter 1990, pp. 71-91), is strictly linked to innovation. The aim of the study is to show the use of network analysis organization in building innovative teams on the example of enterprise energy sector.

\section{Competitiveness and innovation}

Competitiveness is a feature which should be taken into account and should determine the processes of formulating an enterprise's development strategy (Obłój 2007, p. 17). For the purpose of this paper, it can be assumed that it is a multi-dimensional feature of an enterprise. It results from its internal characteristics, and is also tied to the enterprise's ability to adapt to changes in the environment. Definition of the concept of competitiveness results both from the resource-based and position-based approaches. According to the resourcebased approach, definition of the organization's strategy should be based on its identified resources. Both in the context of the material and non-material potential. Conversely, the position-based approach assumes that the building of competitive advantage depends on the conditions present in the environment. According to this approach, the conditions in which the organization operates influence the final outcome of competition. However, under that approach the basis to build competitive advantage is the set of key competences of the organization. The question always remains, which of the competences are key and whether they would be able to build the organization's winning competitive advantage. In order to be competitive, organizations undertake numerous activities. However, as it results both from the business practice and from analysis of the relevant literature, the competitiveness does not have a set of unanimously defined factors which shape it. Of course both the researchers and practitioners cite a "set of factors" as the source of competitiveness (Skawińska 2002 p. 17, Szymański 1995, p. 156, Abdul-Jalal et al. 2013, p. 154), but these are defined almost exclusively through context. They each time refer to precisely defined areas of the organization, or to specific situations in which the given organizations functioned. The challenge for the organization is to create a set of the right features of competitiveness. Hofer and Chendler (Hofer et al., 1978, p. 3) point out a set of areas where winning characteristics can be defined: the areas of financial, physical, human, organizational and technological resources. In a slightly different manner, the resource-based school cites the following areas:

Using the organizational network analysis to build competitiveness on the example of enterprise energy sector 
financial, physical, human and organizational. The Strategor group indicates three areas: organizational, managerial and psychological; and indicates among them the areas where winning characteristics should be sought.

However, understanding competitiveness as the achievement and creation of competitive advantage - in order words, placing the enterprise in a position better than the competitors (Wawrzynek 2014, p. 64), it is worthy paying attention to Porter's consideration, who states that innovation is the fundamental factor for gaining competitive advantage, irrespective of the context in which the organization operates (Porter 1990, pp. 71-91). It seems that, based on this assumption, an important direction for building competitiveness of an organization is to search for those development areas which do not stem from the current products or services, but refer to other areas which are not yet present in the market. Similarly as M.E. Porter, also C. Gubbins and L. Dooley (2014 p. 162) point out that the competitiveness of a modern organization depends on its ability to effectively launch innovations. Implementation of innovations within the organization is meant to fill the new market areas and products, which could result in increase of its competitiveness. Based on innovation, its identification, stimulation, production and finally commercialization, as on the element which builds the market and products in new spaces, it can be assumed that innovation can be the basis to build and maintain competitive advantage.

Actions tied to identification of innovation - in other words, search for its sources - should be focused on people. This stems, for example, from the assumptions of Gratton and Illes, who state that innovation results directly from the knowledge, skills and competences (Gratton 2000, pp. 128-146, Iles 1996, pp. 73-76). These in turn, in the most powerful manner, are the province of players within the organization, or the employees. However this knowledge, possessed by the employees, escapes a clear identification and frequently cannot be systematically transferred. It does seem that its sources can be identified with the available organizational analysis tools. Primarily through focusing on the persons who particularly stand out by their high level of knowledge and attitudes typical for the development of innovation. Aside from pure identification of such persons, the organization should act to stimulate a higher level of their innovative potential. Such actions are understood as stimulation of and support for mechanisms for sharing knowledge, as well as mechanisms for strengthening the innovation potential of individuals. Innovative actions and the sharing of knowledge initiated by persons who possess them is possible only in situations where positive emotions, dedication and trust are present. Otherwise, as Gratton (2000, pp. 15-19) indicates in his research, where there is a sense of 
lack of trust and restraining of emotions, employees will not share knowledge, and their innovative potential and creativity would be suppressed. Indicating those areas tied to the reception of certain conditions by the employees, the organization must understand the internal stimuli for their behaviors. Barabási however states that we are unable to understand actions of individuals if we ignore the complex interaction networks of these individuals (Barabási 2012, p. 150). Therefore, the contextual understanding of individuals' relations in their interactions with other persons in the organization is crucial. It is particularly important to understand these relations as regards the bonds of trust, dedication and knowledge sharing.

The issue of innovativeness itself becomes a priority for the organization's development (Okatan 2012, p. 59). The use of an organization's knowledge, its sharing and exploitation to boost innovation is one of the foundations of the classical approach to understanding innovativeness of an organization. The concept of innovation and innovativeness is a complex one and refers to such elements as the development of new concepts (products or services), their rapid manufacture and market supply. Under the traditional understanding of the process for innovation management, popularized by Schumpeter, three stages can be identified (Schumpeter 1961):

- invention - the phase during which ideas are developed,

- innovation - the phase during which the new services/products are marketed,

- imitation or diffusion - the phase of spreading the new services/products in the market.

Innovativeness is defined in a similar manner by Van de Ven and Angle (1989, p. 20) - as the generation, acceptance, adoption and implementation of new ideas, processes, products or services. At each of these stages, the success of innovation depends on the availability of knowledge (Okatan 2012, p. 59). The use of knowledge is context-linked with creativity, which is defined as approach to work resulting in the generation of new, appropriate ideas, processes and solutions (Amabile 1996, p. 90). However, knowledge in the organization is divided into tacit and explicit knowledge, as well as into content-related and auxiliary knowledge (Hall, Adriani 2002, p. 30). In innovation, it is necessary to use both types of knowledge: the tacit, acquired through experience, and the explicit. Tacit knowledge is always in a closer proximity to the individual able to interpret it, while explicit knowledge can also be stored in the organization's systems. Innovation understood as the element of the invention phase, based on the J.A. Schumpeter (1961) approach, is tied more to the use of tacit knowledge. Its connection to the sense of dedication, understanding and to individual 
characteristics of the individual shall define the level of innovation potential. Knowledge, the indispensable element of an organization's innovativeness, is tied primarily to the first two phases of implementing innovation (figure 1), to which further parts of this study refer:

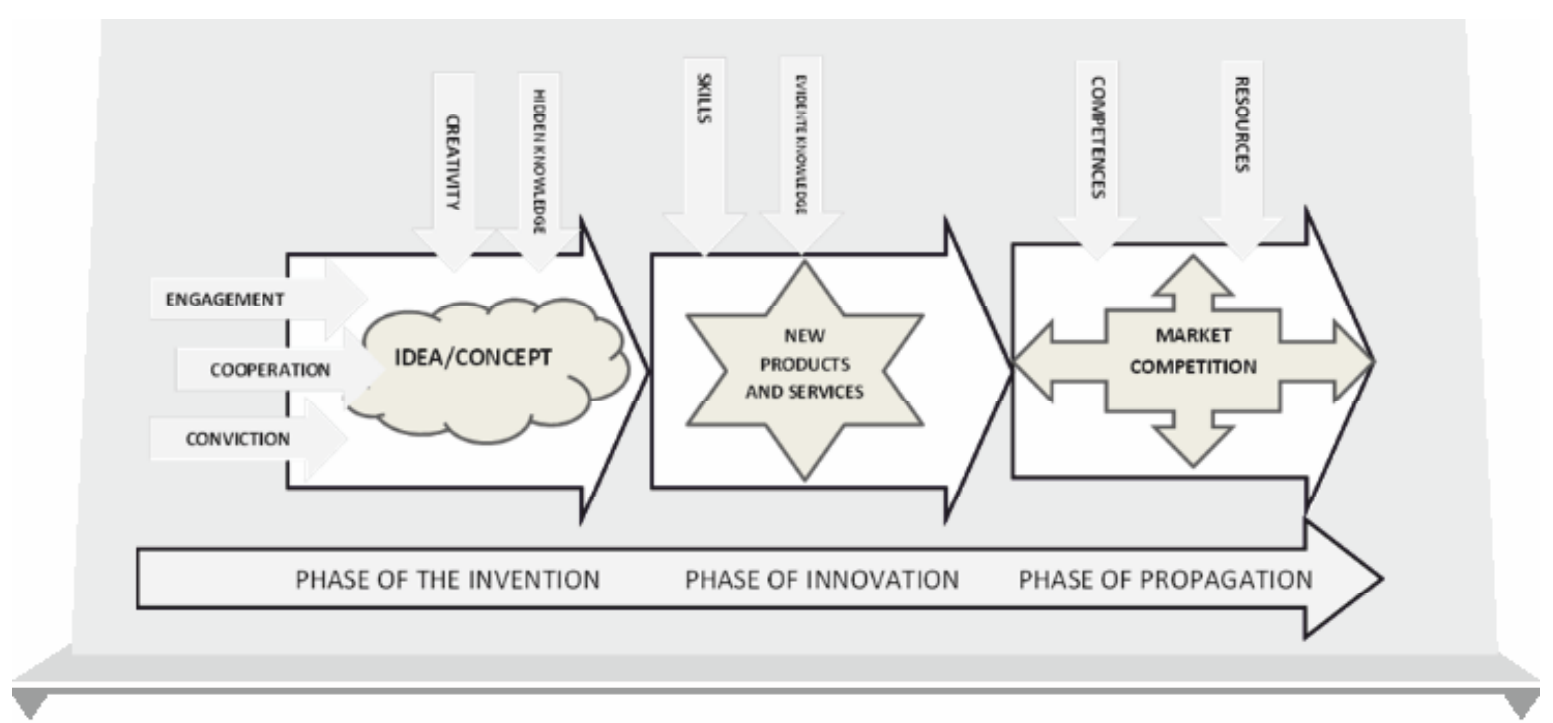

Figure 1. Knowledge at the phases of innovation development

Source: own study

The challenge for the managers on the road to achievement of competitiveness is how to stimulate innovation through supporting cooperation, building of trust and transferring or stimulating the transfer of knowledge.

\section{Organizational networks analysis}

Organizational networks analysis (ONA) is a tool which enables the organization to understand the relationships among its participants. Despite the fact that managers frequently believe they know the relations within their organization, according to research conducted by D. Krackhardt and J.R. Hansen (1993 p. 104) they are able to reproduce the social connections among those five or six people in their closest proximity, and their beliefs regarding relations among employees outside their direct circles are usually off-the-mark. In order to understand whether the bonds of trust, cooperation or potential for knowledge sharing indeed occur among employees of an organization, one can 
use the opportunities offered presently by organizational networks analysis. The ONA owes its creation to the social sciences, however, nowadays it is strongly embedded in the management sciences. The ONA method enables the identification of various elements of relationships within organizations, assumed in the research. The approach is based on observation of actual occurrences, which creating a defined environment of the author create the opportunities and limitations for his behavior (Borgatti, Foster 2003, p. 1000). Through the identification of actual dependencies among people in an organization, the ONA offers the opportunity for understanding the inner structure for exchange of knowledge, communication, as well as the dependencies of cooperation or bonds of trust. Thus, it offers the possibility for illustrating mechanisms which can stimulate or reduce the innovation potential of an enterprise.

The network of relations is the structure of bonds among people. It refers to a specific set $\{1 \ldots \mathrm{n}\}$ of persons (actors) and variables $X \mathrm{ij}$, which indicate the links between the actor $i$ and the actor $j$. There exist directed relations $X \mathrm{ij}$, which differentiate a relation $X_{i j}$ from the relation $X_{j i}$, despite the fact of connecting the same two actors, and relations $\mathrm{Xij}$ and $\mathrm{Xji}$ which define the same relation (non-directed relations). The ONA is most frequently characterized by binary Xij relations, where the value of 1 (or 0 ) indicates the presence (or absence) of relation between the actors $i$ and $j$. The element consisting of a set of persons (actors) $\{1 \ldots \mathrm{n}\}$ and the $\mathrm{Xij}$ relations is known as graph in mathematics. Under this approach, the actors are the nodes, and the relations are the edges of the graph. It is also assumed that a relation with oneself is characterized by the zero value, as it does not present relations among persons in the organizations. The measures of matrices known as distance matrices are the degrees which, based on their negative or positive values, show the number of outgoing relations (out-degree) or the number of relations incoming to the system (in-degree). Those measures indicate the strength of influence exerted over other individual or networks, or by other entities or networks within broader systems of relations. Social networks can be used to define various characteristics: reciprocation, homophily, transitivity, degree diferentials or hierarchies (Snijders 2011, pp. 4-6).

Analysis of the network of communication, information, trust or cooperation can offer extensive informative benefits for understanding the functioning of persons within an organization. Having an image of systems of relations which influence the overall relations among employees of an organization, the managers can use this knowledge to stimulate situations which boost the level of innovation within the organization, and thus support it in the achievement of a higher level of competitiveness. 


\section{The context of a competitiveness-building organization}

As the result of a study conducted at one of the international service and manufacture company from the power sector, which operates several business units in Poland, on the basis of the organizational network analysis this company undertook actions meant to remodel the system of employee teams, in an attempt to increase their innovation level.

The study covered a group of more than 400 persons, operating within less than 10 locations in Poland and within a system of a few core areas. The purpose of this study was to identify persons who in the future could build a team characterized by a high level of innovation. The research assumption was that the innovation potential of the team would result from the relations of individual persons within the network of cooperation, trust, communication and innovation. In addition, it was assumed that an important element for effective functioning of the team would be the high potential for organizational changes, which would additionally result from archetypical roles and the strength of individuals' influence in relationships with other actors.

The study was conducted in late 2015/early 2016. Data was collected through an online questionnaire, which was mailed to a selected group of managers from the organization. The questionnaire focused on several issues which were the basis, during the analysis stage, to formulate conclusions referring to the identification of innovative attitudes, to the identification of relations within communication systems, to the identification of relations of cooperation and trust among persons participating in the research and among other players in the organization, indicated by the research participants. As the study was meant to identify persons possessing the indicated characteristics, each time a new person, not yet covered by the research, was named, he or she received the research questionnaire in order to complete the results of the ongoing study.

The second dimension of the analysis was to identify persons who possess characteristics tied to the archetypical roles and who exert a significant influence within the identified system of relations. The archetypical roles were tied to their characteristics in the building of innovation potential, and identified on the basis of assumptions for managerial roles concept, suggested by M. Kets de Vries (2013), and with regard to concept of managerial roles named by G. Bełz (2011) as the synthesis of multiple criteria for managerial roles, discussed in the relevant literature. Under the archetypical roles, the managerial, leadership and entrepreneurial roles were isolated. Within the 
group of the so-called key persons, key persons for the dimension of networks cited above were identified.

The study results were presented in graphic form, and were supplemented with the values of the individual indicators, relevant for the decisions faced by the managers in the organization. In figure 2 we can see the layout of communication network, in figure 3 the layout of cooperation network, in figure 4 the system of innovation, while figure 5 shows the system of trust-based relations network, indicating persons in particular locations and holding particular functions (which is illustrated in color).

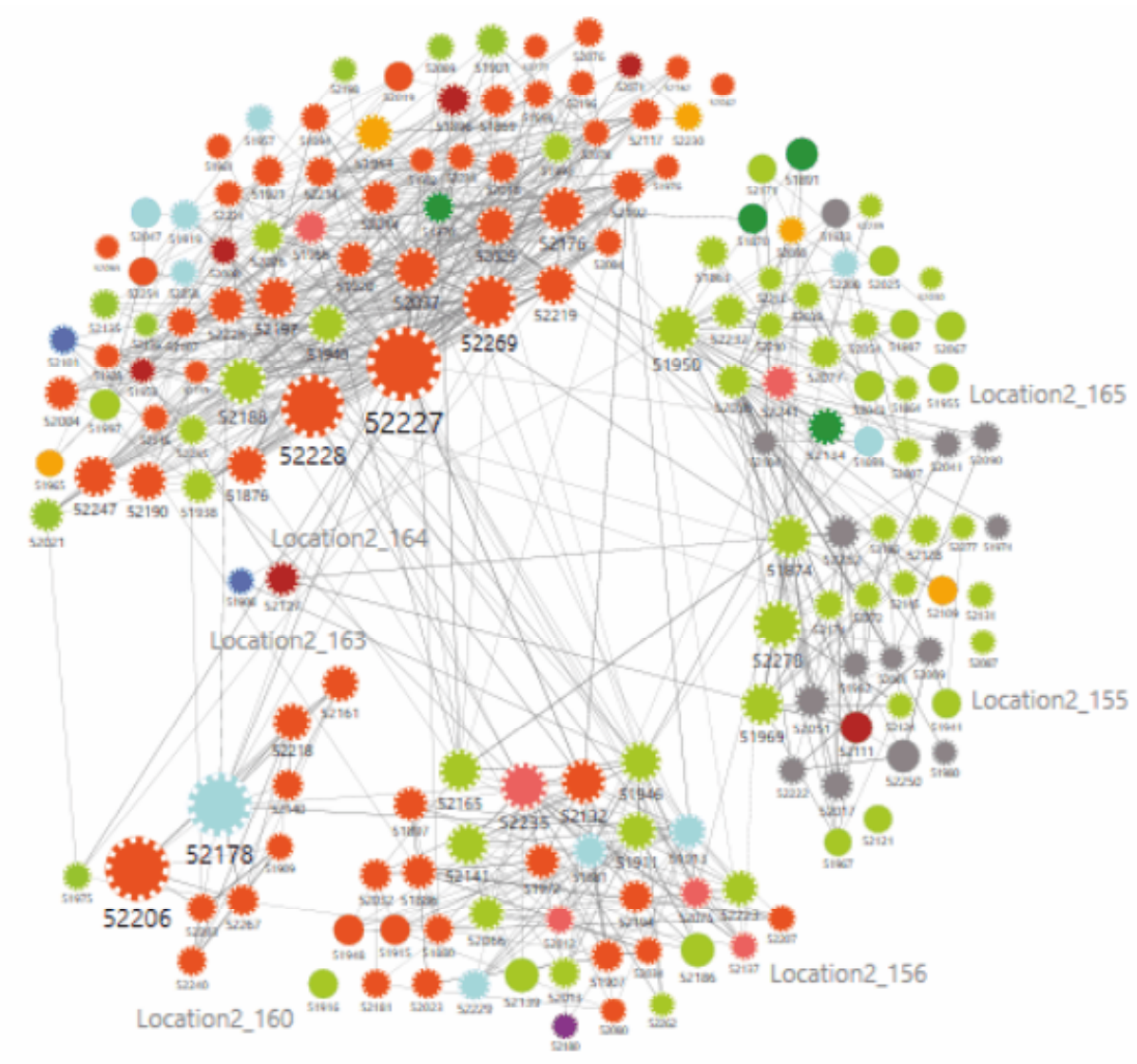

Figure 2. The layout of the communication network relations, broken down per location of business units in Poland

Source: own work on the basis of the study 


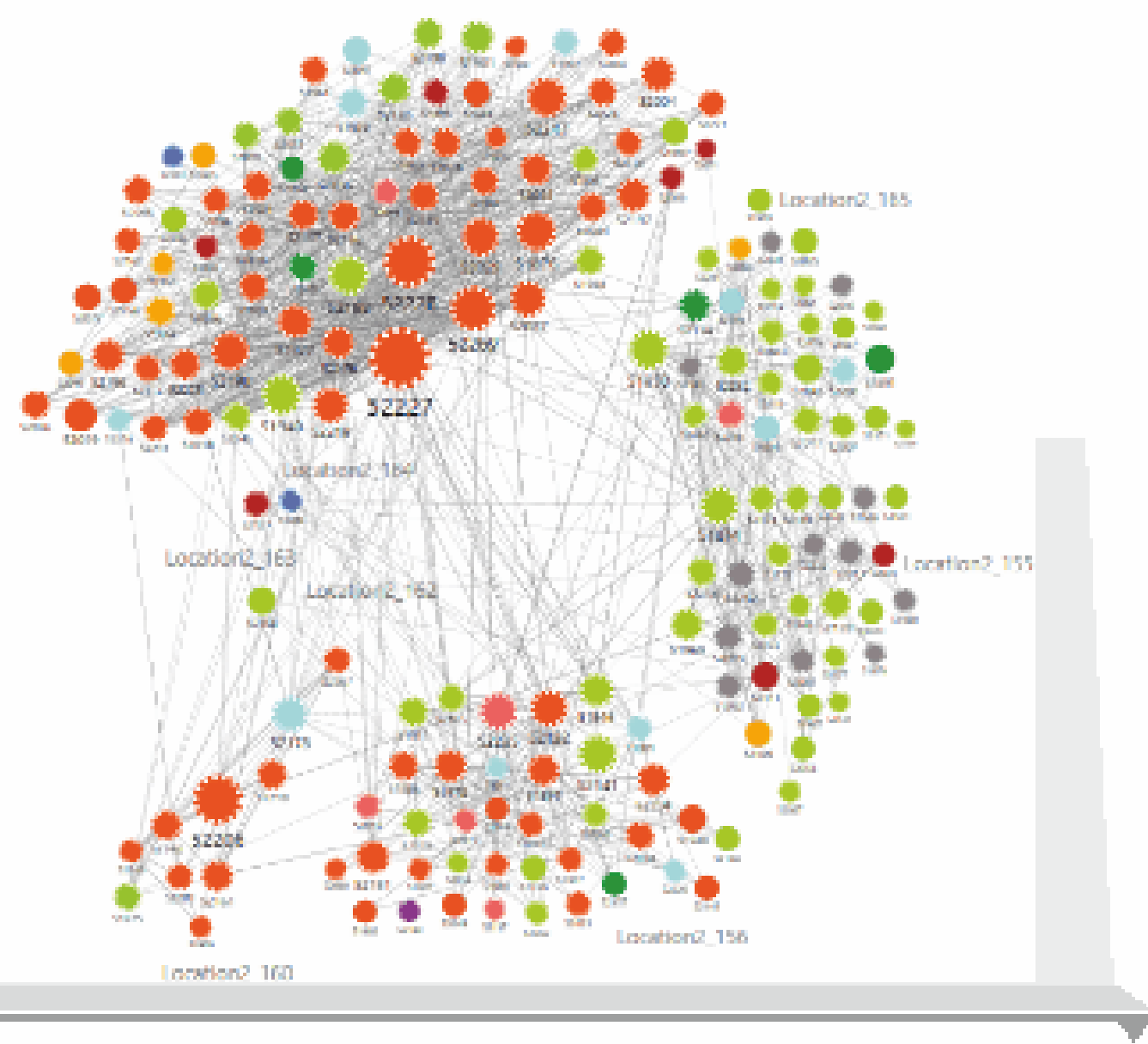

Figure 3. The layout of the coaperaton network radatlons, broken down por loctklos of businest unite ln Poland

Faure: awn thork an tlu busis of tye study

Figures 6 and 7 illustrate, respectively, the ego network of a selected person, core from the network's perspective, taking into account the closest links and (figure 7) taking into account all the links of the selected person within the communication network relations.

During the subsequent step, the study results and analyses were presented and discussed with decision-makers of the organization in Poland, who on the basis of organization strategy and study conclusions made a decision to set up a new team within the enterprise. The newly established team, monitored from the standpoint of indicators tied to generation and implementation of innovations, 


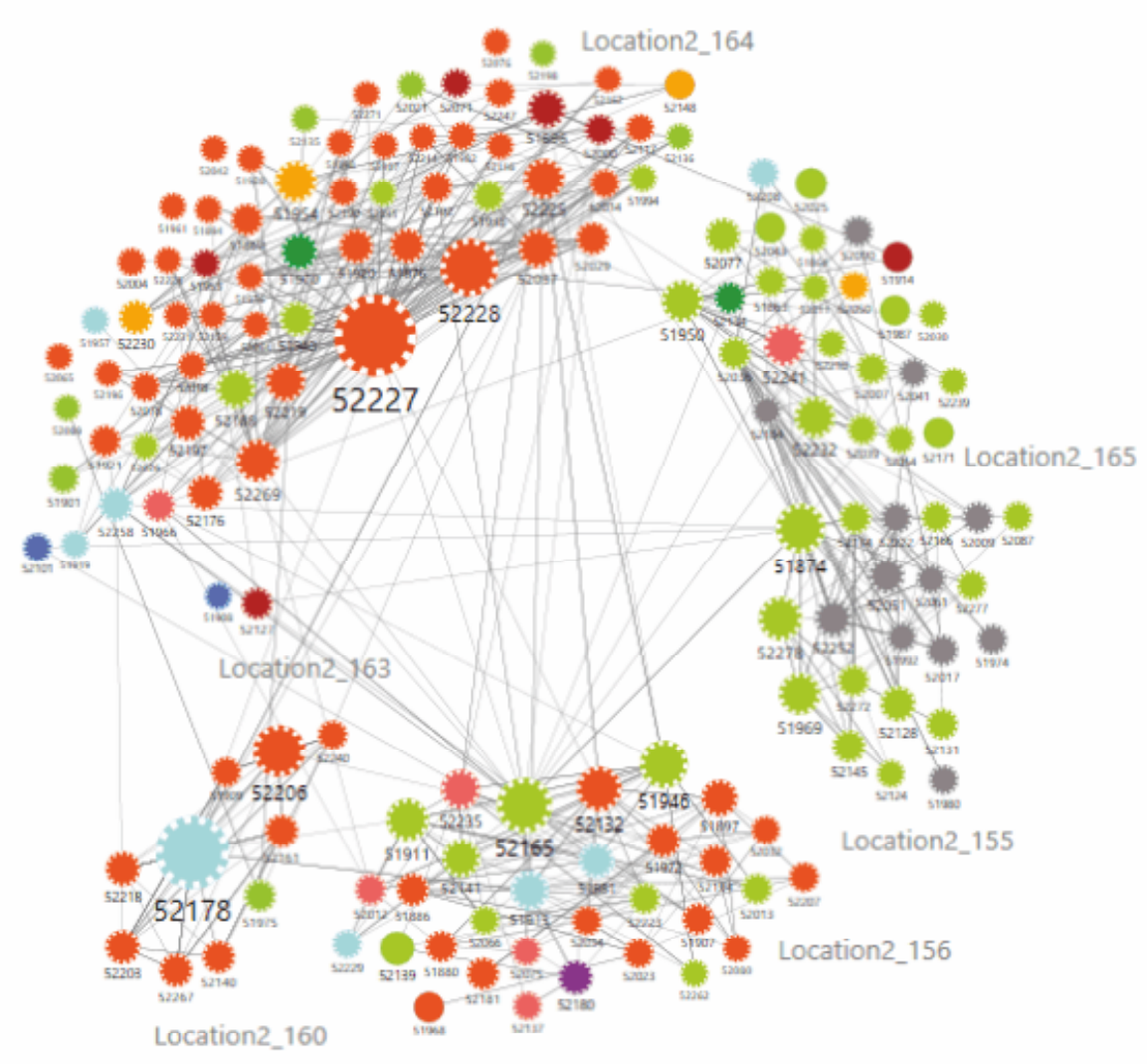

Figure 4. The layout of the innovation network relations, broken down per location of business units in Poland

Source: own work on the basis of the study

was compared against other teams. As regards the comparison of results tied to the creation of innovative ideas (measured as the number of generated ideas regarding improvements, launch of new products and services) and to their implementation (value added of implemented solutions), the newly created team, during its first months of operations, achieves results visibly higher than those of other teams.

Certainly, the question arises here, to what extent the knowledge resulting from organizational network analysis was the basis to set up the team with those, and not others, members. However, based on the initial plans of the organization regarding the composition of the new team, looking at its final composition it 


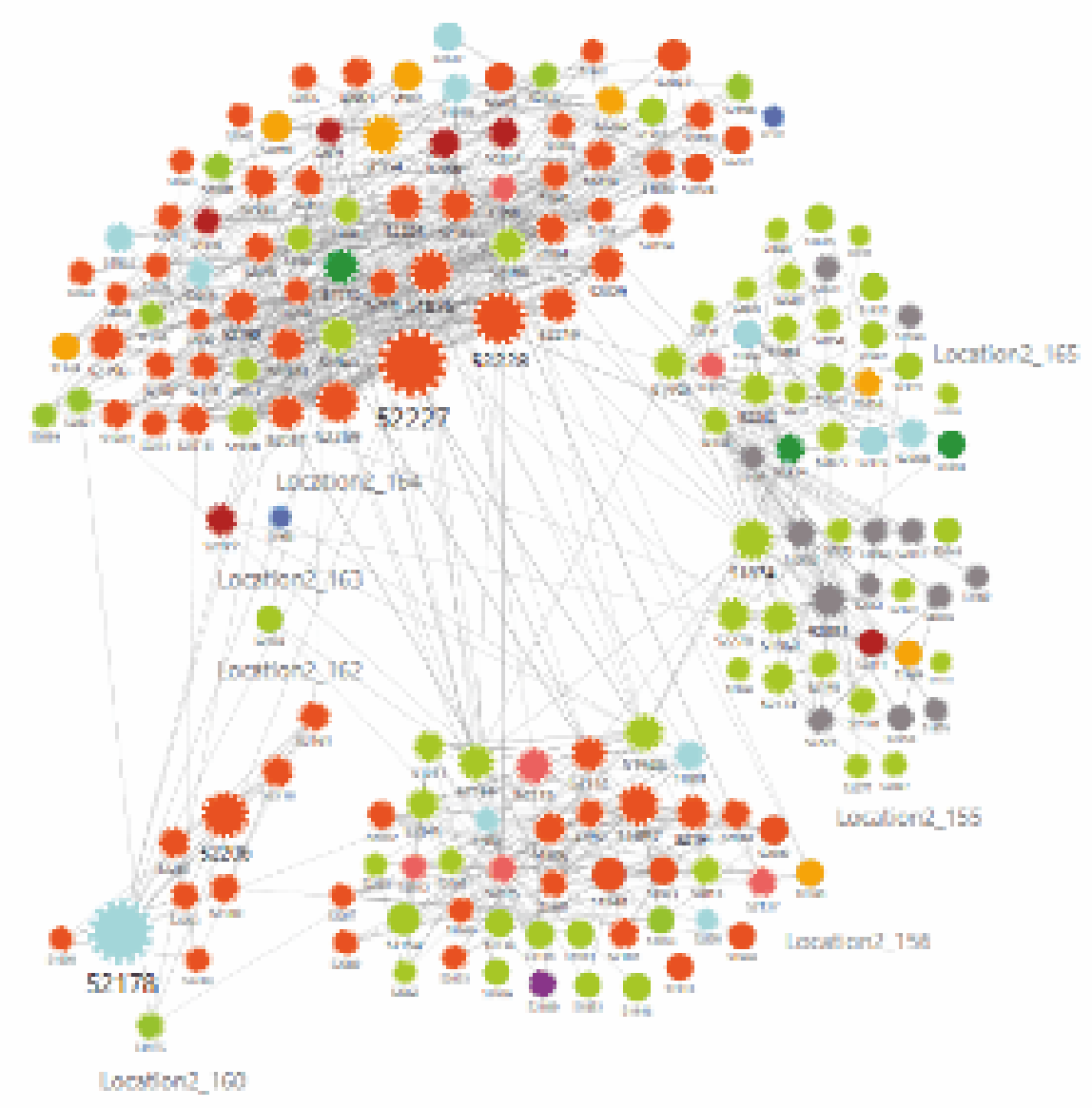

Flgure 5. The leyrut of the trut network roletlens, broken down pr lacation of husiness units in Poland

Saure: awn hork an tlu busis of thle study

can be said that around one-third of members were selected on the basis of study results, their discussion and on the basis of measurable values based not only on graphic presentation of relations, but also on indicators presented in the course of the study.

The second question which arises - aside from the target manner for assessing innovativeness of the team - is tied to its innovation capacities in a situation where the selection would be based only on the earlier observations by decisionmakers and on the organization's strategy. Unfortunately here we have no 


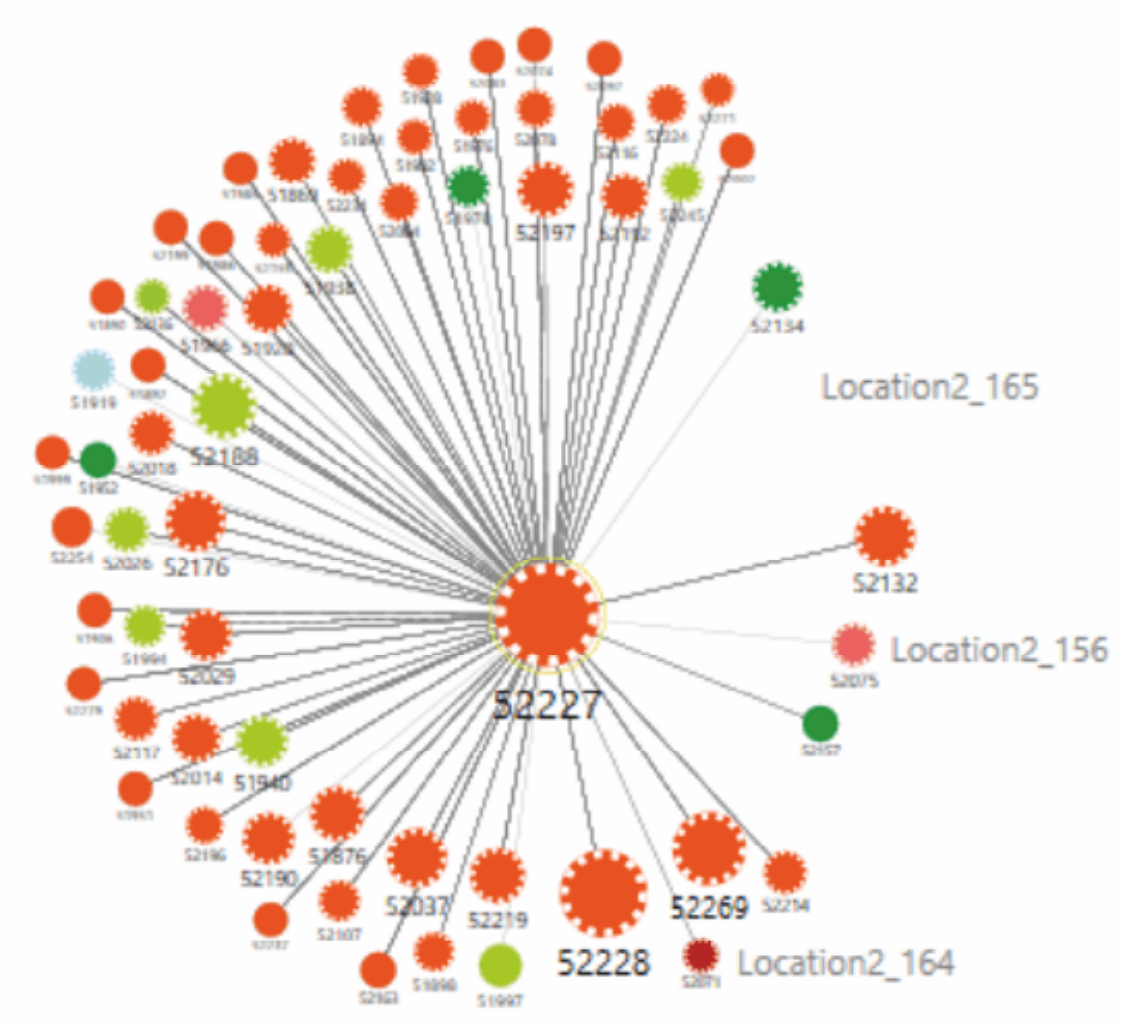

Figure 6. Ego network (network of the closest relations) of the key person within the communication network

Source: own work on the basis of the study

opportunity for verification, but it appears that the selection made on the basis of various sources - including the study results - was apt.

\section{Conclusions}

On the basis of the analysis conducted within an organization comprising numerous business units, operating under dispersed architecture, and based on the indicators describing results achieved through the application of organizational networks analysis, it can be concluded that in the given situation this tool can contribute to increased innovativeness, and thus to increased competitiveness of the organization in question. Given the various types of 
organizational networks, and therefore analyzing the relations which seem to be the foundation for generating innovations which involve communication, trust, cooperation or simply perception of other employees as potential sources of ideas and innovation, it is possible to note the uneven distribution among relations. Such situations could be the basis to stimulate interventions in areas where there are no elements required to ensure the increase of innovation level. On the other hand, as illustrated by the above example, they can be the basis to build new teams, which acting together achieve better results than previously, in terms of developing innovation and supporting the organization's competitiveness.

\section{Summary}

Using of the organizational network analysis to build competitiveness on the example of enterprise energy sector

Contemporary organizations operate in dynamic, complex markets. One of the directions of their development is the increase of competitiveness level. This level must be based on factors for building competitive advantage, clear for the given organization, or, in a broader sense, based on general conditions for the increase of competitiveness. One of these directions could be innovation, which would lead to development and the gaining of new markets. Being innovative depends on the ideas and their implementation. This in turn depends on knowledge, primarily tacit knowledge, which is associated with the employees. To identify it, and next lead to its diffusion and application, the organization must learn the dependencies in which employees function, and match to them certain actions that would result in the increase of innovation potential. The learning of the actual relations is possible with the application of the organizational network analysis. This paper presents an example of applying organizational networks in an enterprise, on the basis of a conducted study. The results suggest that such tools are useful and that the organization, after the interventions it launched, achieves in the analyzed area a level of competitiveness higher than in other areas.

Keywords: organizational network analysis, competitiveness, innovation, key players

\section{Streszczenie}

Wykorzystanie analizy sieci organizacyjnej $w$ budowaniu 


\section{konkurencyjności na przykładzie przedsiębiorstw branży energetycznej}

Nowoczesne organizacje działają na dynamicznych, złożonych rybkach. Jednym $\mathrm{z}$ kierunków ich rozwoju jest podnoszenie poziomu konkurencyjności. Ten zaś musi opierać się na jednoznacznych dla danej organizacji czynnikach tworzenia przewagi, lub, patrząc szerzej, w oparciu o ogólne kierunki wzrostu konkurencyjności. Jednym z kierunków może być innowacyjność, która prowadzić będzie do rozwoju i zdobywania nowych rynków. Bycie innowacyjnym uzależnione jest od pomysłów i ich wdrażania. Te zaś od wiedzy, głównie ukrytej, która jest związana $\mathrm{z}$ pracownikami. Aby ją zidentyfikować a następnie doprowadzić do jej dyfuzji i wykorzystywania, organizacja musi poznać zależności w jakich funkcjonują pracownicy i dopasować takie działania skutkujące wzrostem potencjału innowacyjnego. Poznanie faktycznych relacji jest możliwe $\mathrm{z}$ wykorzystaniem analizy sieci organizacyjnej. W artykule zaprezentowano, na podstawie przeprowadzonych badań, przykład zastosowania sieci organizacyjnych w firmie. Wyniki wskazują, że narzędzia takie są pomocne, a organizacja $w$ ramach przeprowadzonych interwencji osiąga, w analizowanym obszarze, wyższy niż przeciętnie $\mathrm{w}$ innych obszarach poziom innowacyjności.

\section{Słowa}

kluczowe: analiza sieci organizacyjnych, konkurencyjność, innowacyjność, kluczowi gracze

\section{References}

1. Amabile T., M. (1996), Creativity in Context, Westview Press, Nowy Jork.

2. Barabási A., L. (2012), The network takeover, "Nature Physics", Vol 8, January 2012, pp. 14-16.

3. Bełz G. (2011), System zarządzania jako regulator odnowy $i$ wzrostu przedsiębiorstw, Wydawnictwo Uniwersytetu Ekonomicznego we Wrocławiu, Wrocław.

4. Borgatti s., P., Foster P., C. (2003), The Network Paradigm in Organizational Research: A Review and Typology, w: "Journal of Management" 29(6) pp., 991-1013.

5. Gratton, L., (2000), Living strategy: Putting people at the heart of corporate purpose. FT Prentice Hall, London 
6. Gubbins C., Dooley L. (2014). Exploring Social Network Dynamics Driving Knowledge Management for Innovation, "Journal of Management Inquiry" Vol. 23(2), pp.162-185.

7. Hall R., Adriani P. (2002), Managing Knowledge for Innovation. “Long Range Planning" 35, pp. 29-48.

8. Hofer C., W., Schendel D. (1978), Strategy formulation: Analytical concepts. St. Paul, MN: West.

9. Kets de Vries M., F., R. (2013). The Eight Archetypes of Leadership, https:// hbr.org/2013/12/the-eight-archetypes-of-leadership/\# (18.06.2015).

10. Krackhardt D., Hanson J., R. (1993). Informal Networks: The Company behind the Chart [in:]"Harvard Business Review", 71/4 (July/August 1993), pp.104111.

11. Okatan K., (2012) Managing knowledge for innovation and intra networking: a case study. "Procedia - Social and Behavioral Sciences" No. 62, Published by Elsevier Ltd., pp. 59 - 63.

12. Porter M., E. (1990), The Competitive Advantage of Nations, „Harvard Business Review", March-April 1990, pp. 71-91.

13. Schumpeter J., A. (1961). The Theory of Economic Development: An Inquiry Into Profits, Capital, Credit, Interest, and the Business Cycle. Oxford University Press, Nowy Jork.

14. Snijders T., A., B. (2011) Statistical models for social networks, [in:]:"Annual Review of Sociology", 37, pp. 129-151.

15. Van de Ven, A., H., Angle H., L. (1989). An introduction to the Minnesota Innovation Research Program w: "Research on the Management of Innovation". Harper Row, Nowy Jork, pp. 3-30.

16. Wawrzynek Ł. (2012), System zarzadzania w procesie odnowy organizacyjnej, $\mathrm{w}$ : Strategie i mechanizmy odnowy przedsiębiorstw, Bełz G., Cyfert S. (eds.), Wydawnictwo Uniwersytetu Ekonomicznego we Wrocławiu, Wrocław, pp. 154-161.

17. Wawrzynek Ł., (2014), Wykorzystanie metody DEMATEL w budowaniu konkurencyjności, [in:] Management Forum, 5/2014, pp. 64-74. 